\title{
FAMILIAL CANCER
}

\section{Depressed NK-cell cytotoxicity in healthy and cancer affected members}

\author{
Terezinha C.B. Montelli', Maria Terezinha S. Peraçoli², Roberto C. Gabarra², \\ Angela M.V.C. Soares ${ }^{2}$, Cilmery Suemi Kurokawa ${ }^{2}$
}

\begin{abstract}
Depressed natural killer (NK) cell activity has been showed in family members of patients with different types of cancer. The present work aimed to evaluate T cell subsets and NK cell cytotoxic activity in 15 members of a family with high incidence of tumors, such as glioblastoma, gastric, pancreas and colon rectal carcinoma, chronic myelocitic leukemia, melanoma and osteoblastoma. As controls, 19 healthy subjects with the age range equivalent were studied. The enumeration of CD3+ lymphocytes and their CD4+ and CD8+ subsets were defined by monoclonal antibodies and NK cell cytotoxicity towards K562 target cells were evaluated by single cell-assay. The results showed in family members low percentage of total T cells $(C D 3+)$, and their CD4+ subset and impairment of CD4/CD8 ratio in relation to control group. All family members presented percentage of NK-target cell conjugate formation bellow the minimum value observed in control group. Thirteen people were examined and followed up during five years, in order to assure that there was no undiagnosed or unsuspected disease at the moment of evaluation. One of them developed osteoblastoma and other malignant melanoma. Two cancer patients, with glioblastoma and chronic myelocytic leukemia were studied during illness. All the corresponding values were comparable. The persistence of low percentage of conjugate formation may be related to a defect on adhesion molecules expression in the surface of NK cells that was probably responsible for the low activity of these cells presented by the family group. Thus, the inheritance mechanism of low adherence of NK cells should have a prognostic value in determining the risk of developing tumors.
\end{abstract}

KEY WORDS: familial cancer, glioblastoma, cytotoxic activity, natural killer cells, T cell subsets.

\begin{abstract}
Câncer familiar: depressão da atividade citotóxica de células natural killer em indivíduos sadios e pacientes com diferentes tipos de câncer

RESUMO - Este estudo se reporta às funções de células natural killer (NK), como adesão, lise e citotoxicidade e de subpopulações de células T em uma família com alta prevalência de pacientes com câncer e que apresentaram: glioblastoma, leucemia mielóide crônica, osteoblastoma, melanoma e carcinomas gástrico, pancreático e cólon retal. Quinze membros dessa família foram estudados, sendo 13 sadios, acompanhados por 5 anos e dois com câncer: glioblastoma e leucemia mielóide crônica. Duas pessoas sadias, no momento da avaliação, desenvolveram posteriormente osteoblastoma mandibular ou melanoma maligno. Como controle, foram avaliados 19 indivíduos saudáveis de faixa etária equivalente. A determinação de linfócitos T CD3+ e de suas subpopulações CD4+ e CD8 + foi realizada empregando-se anticorpos monoclonais e a atividade citotóxica de células NK, avaliada pelo teste de single-cell contra células alvo da linhagem eritroleucêmica K562. Os resultados mostraram que as percentagens de células $T$ totais $(C D 3+)$, da subpopulação $C D 4+$ e da relação CD4/CD8 foram significativamente menores nos indivíduos da família estudada em comparação aos valores observados no grupo controle. Em todos os membros dessa família a percentagem de formação de conjugados entre células NK-células alvo foi inferior ao valor mínimo observado nos controles. Essa alteração poderia estar relacionada a defeito na expressão de moléculas de adesão, presentes na membrana de células NK, como provável causa das alterações funcionais dessas células. A herança dos mecanismos determinantes desta deficiência pode ser um fator de risco, com valor prognóstico para o desenvolvimento de cancer.
\end{abstract}

PALAVRAS-CHAVE: cancer familiar, glioblastoma, atividade citotóxica, células NK, subpopulações de células T.

'Departamento de Neurologia e Psiquiatria, Faculdade de Medicina, e 2 Departamento de Microbiologia e Imunologia, Instituto de Biociências, Universidade Estadual Paulista (UNESP), Botucatu, São Paulo, Brasil.

Received 3 July 2000, received in final form 31 August 2000. Accepted 6 September 2000.

Dra Terezinha C. Braga Montelli - Departamento de Neurologia e Psiquiatria, Faculdade de Medicina de Botucatu-UNESP - 18618-000 Botucatu SP - Brasil. Email:montelli@laser.com.br 
Alterations in tumor susceptibility genes by themselves may not be sufficient to cause cancer ${ }^{1}$. Modifier functions that could play a role in governing susceptibility to malignant disorders need to be better understood. Cytotoxic lymphocytes constitute the major anti-tumor effector cell population. Natural killer (NK) cell function is recognized for its involvement in resistance against tumor growth and dissemination and constitutes a generalized cytolytic mechanism. NK cells have long been implicated as an important modifier of susceptibility to tumors, particularly in murine models. Data regarding NK cell function in relation to protection against cancer in humans remains suggestive ${ }^{2-6}$. The mechanisms by which NK cells act against cell tumors include a secretory/necrotic killing and a non-secretory/apoptotic killing against a larger variety of tumor cell lines $^{7}$. Thus, these cells seem to be the unique immune cells with constitutively multiple mechanisms of destroying abnormal cells. Low levels of NK cell activity was found to be associated with a high incidence of familial cancer in general ${ }^{5}$. Otherwise, recent studies indicate that NK cell function can be inherited $^{7}$ as a recessive trait ${ }^{8}$.

Impaired lymphocyte activation is a common feature in cancer patients ${ }^{6}$. Our group studied the cytotoxic activity of NK cells and T cell subsets in peripheral blood of 13 patients with primary tumors in central nervous system (CNS) ${ }^{9}$. The results showed that children and adults with tumors in CNS display altered results of cellular immunity, with reduced percentage of total T cells, helper/inducer subset and low helper/supressor ratio. The cytotoxic activity of NK cells, evaluated by single-cell assay was decreased in patients, due mainly to a decrease in proportion of target-binding lymphocytes. However, cohort studies performed on individuals following the onset of overt malignancy are difficult to interpret and compare.

In the present study, we evaluate NK cell activity and $T$ cells subsets in peripheral blood of 11 healthy and 4 affected members of a family with high incidence of cancer. The proband is a woman, 48 years old, with glioblastoma.

\section{METHOD}

\section{Subjects}

A pedigree of the family, which designates the healthy and affected family members, is presented in Figure 1. The age range is 12 to 51 years. This immunological study was performed attenting to family members request. The healthy people were followed up during five years, in order to assure that was no undiagnosed or unsuspected disease at the moment of evaluation. As a control group 19 healthy volunteer hospital personnel, within the age range equivalent to the family, and without history of a cancer in the family were included in the study.

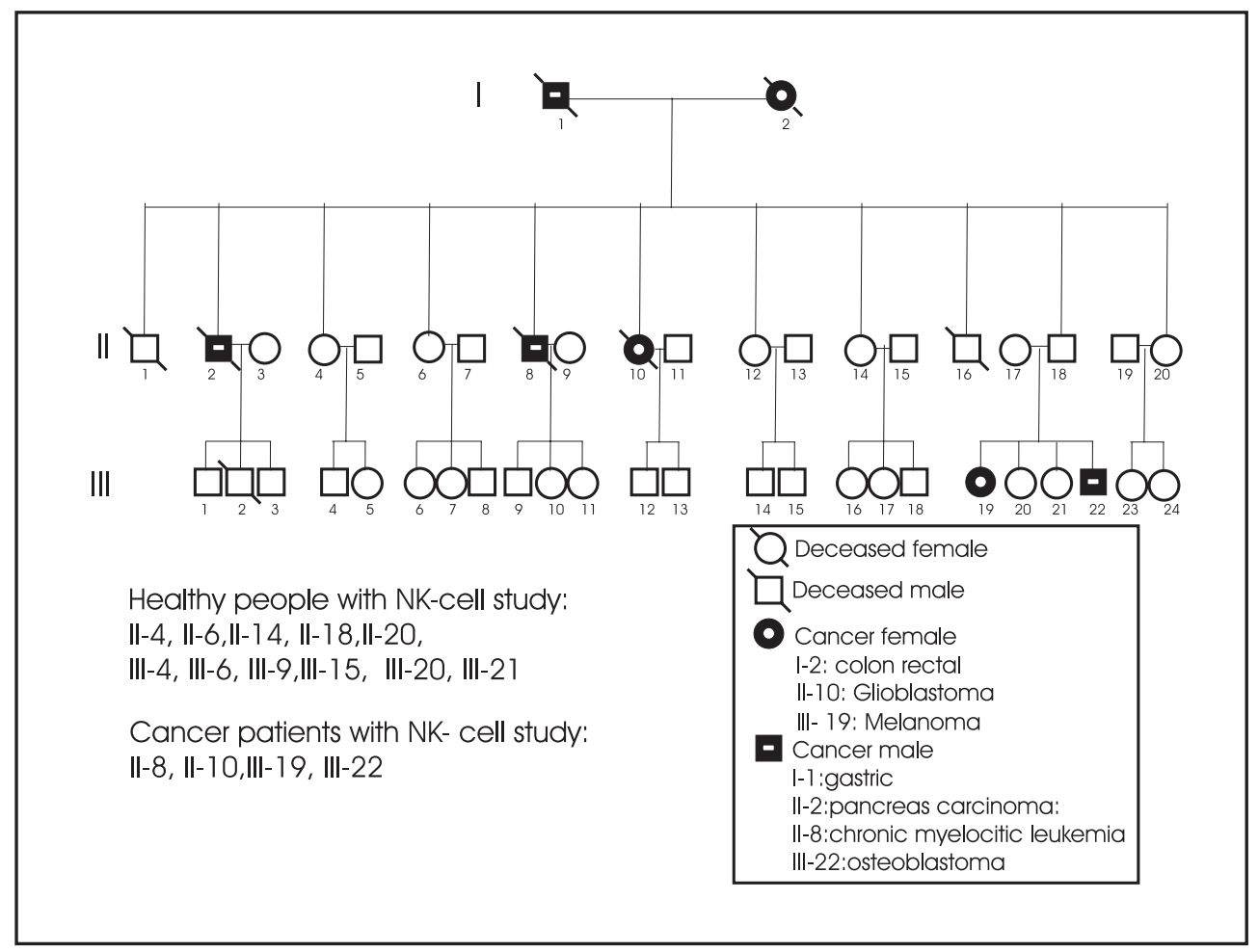

Fig 1. Pedigree of nuclear family. 
Enumeration of lymphocyte subsets

Peripheral blood mononuclear cells were isolated from heparinized venous blood by Ficoll-Hypaque density centrifugation and resuspended in RPMI 1640 medium (Gibco Laboratories, Grand Island, NY, USA) supplemented with $2 \mathrm{mM}$ L-glutamine, $40 \mathrm{mg} / \mathrm{ml}$ gentamicin and $10 \%$ (v:v) fetal calf serum (complete medium). Approximately $2 \times 10^{5}$ cells were centrifuged onto a poly--Iysine-coated coverslip and staining reactions carried out at $4^{\circ}$. $C$ as described previously ${ }^{9}$. Briefly, after reacting with the monoclonal antibody, the cells were treated with biotinylated horse anti-mouse IgG and fluoresceinated avidin-D and fixed in formaldehyde. At least 500 cells per sample were examined under phase and fluorescence microscopy.

\section{Peripheral blood lymphocyte (PBL) preparations}

Peripheral blood mononuclear cells were obtained as described above. Plastic-adherent cells were depleted by incubatiing mononuclear cells on plastic Petri dishes (no. 3003 , Falcon, Oxnard, California, USA) at $37^{\circ} \mathrm{C}$ for $60 \mathrm{~min}$. Non-adherent cells were harvested from plates after gentle shaking, washed and resuspended in complete medium. These PBL were used as effector cells for the NK cytotoxic assay.

\section{Target cells}

The human erytrholeukemic NK-sensitive cell line K562 was used throughout the experiments. The cells were grown to the stationary phase in complete medium. They were subcultured twice weekly and at the day before testing. Prior to the tests, viability was assessed by trypan blue exclusion.

\section{Single-cell cytotoxicity assay}

PBL cells and unlabelled K562 cells were used as effector and target cells, respectively. The single-cell cytotoxicity assay on PLL-coated coverslips was performed as described by Vargas-Cortes et al. ${ }^{10}$ with minor modifications. Effector cell/target cell conjugates were formed by mixing $100 \mathrm{ml}$ of the effector cell suspension with an equal
Table 1. Percentage of $T$ cell subsets in familial healthy and cancer members and in healthy controls.

\begin{tabular}{ccc}
\hline $\begin{array}{c}\text { CD+ cell } \\
\text { subsets }\end{array}$ & $\begin{array}{c}\text { Family members } \\
(\mathrm{n}=15)\end{array}$ & $\begin{array}{c}\text { Controls } \\
(\mathrm{n}=15)\end{array}$ \\
\hline $\mathrm{CD} 3+$ & $52.2 \pm 10.7^{*}$ & $72.6 \pm 3.5$ \\
$\mathrm{CD} 4+$ & $37.7 \pm 11.9^{* *}$ & $48.9 \pm 4.2$ \\
$\mathrm{CD} 8+$ & $26.8 \pm 5.6$ & $26.7 \pm 3.5$ \\
$\mathrm{CD} 4 / \mathrm{CD} 8$ & $1.47 \pm 0.6 * *$ & $1.81 \pm 0.2$ \\
\hline
\end{tabular}

Results are expressed as mean \pm 1 Standard deviation.

${ }^{*} p<0.001$ and ${ }^{* *} p<0.05$ by Student's $t$ test

volume of target cells, both at a concentration of $1 \times 10^{6}$ cells $/ \mathrm{ml}$. After centrifugation at $1000 \mathrm{rpm}$ for $5 \mathrm{~min}$ the cell pellet was incubated for $15 \mathrm{~min}$ at $37^{\circ} \mathrm{C}$ in a $5 \% \mathrm{CO}_{2}$ atmosphere. Control slides containing target cells only were prepared in the same way. The percentage of lymphocytes bound to target cells (\%TBC) was determined by counting 500 lymphocytes. The fraction of conjugates containing dead trypan blue-stained target cells was determined by scoring 100 conjugates. Spontaneous target cell death was determined on lymphocyte-free control coverslips by scoring the fraction of dead (Trypan bluestained) target cells in 300 cells. The fraction of target cell binding lymphocytes that were cytotoxic $(A)$ was calculated as $A=B-(B \times C)$, where $B$ is the fraction of conjugates containing dead target cells, and $C$ is the fraction of spontaneously dead target cells as determined from control coverslips. The percentage of NK effector cells present in the lymphocyte sample was calculated as A $x \%$ TBC.

\section{Statistical analysis}

The results of T cell subsets from familial members and controls were analyzed by Student's test and the comparison between both groups in relation to NK cell parameters was determined by the Mann-Whitney nonparametric test. Significant values are considered to occur at $p<0.05$.

Table 2. Frequency of lymphocyte forming-conjugates and NK effector cells in peripheral blood lymphocytes of family healthy and cancer members and in healthy controls.

\begin{tabular}{cccc}
\hline Groups & $\begin{array}{c}\text { \% Lymphocyte } \\
\text { forming conjugates }\end{array}$ & $\begin{array}{c}\text { \% Lymphocyte conjugates } \\
\text { with dead target }\end{array}$ & \% NK effector cells \\
\hline Family members $(\mathrm{n}=15)$ & $4.78(3.06-7.60)$ & $31.0(18.0-76.0)$ & $1.59(0.88-4.14)$ \\
Controls $(\mathrm{n}=19)$ & $12.0(9.80-15.9)$ & $19.30(13.9-26.2)$ & $2.41(1.61-3.18)$ \\
Significance * & $p<0.001$ & $p<0.001$ & $p<0.01$ \\
\hline
\end{tabular}

$\%$ Lymphocyte forming conjugates were counted per 500 lymphocytes. \% Lymphocyte-target conjugates with dead cells were counted per 100 conjugates. Spontaneous dead target cells were always below $2 \%$ during the assay. Results are expressed as median values with the range in parentheses. ${ }^{*}$ MannWhitney test 


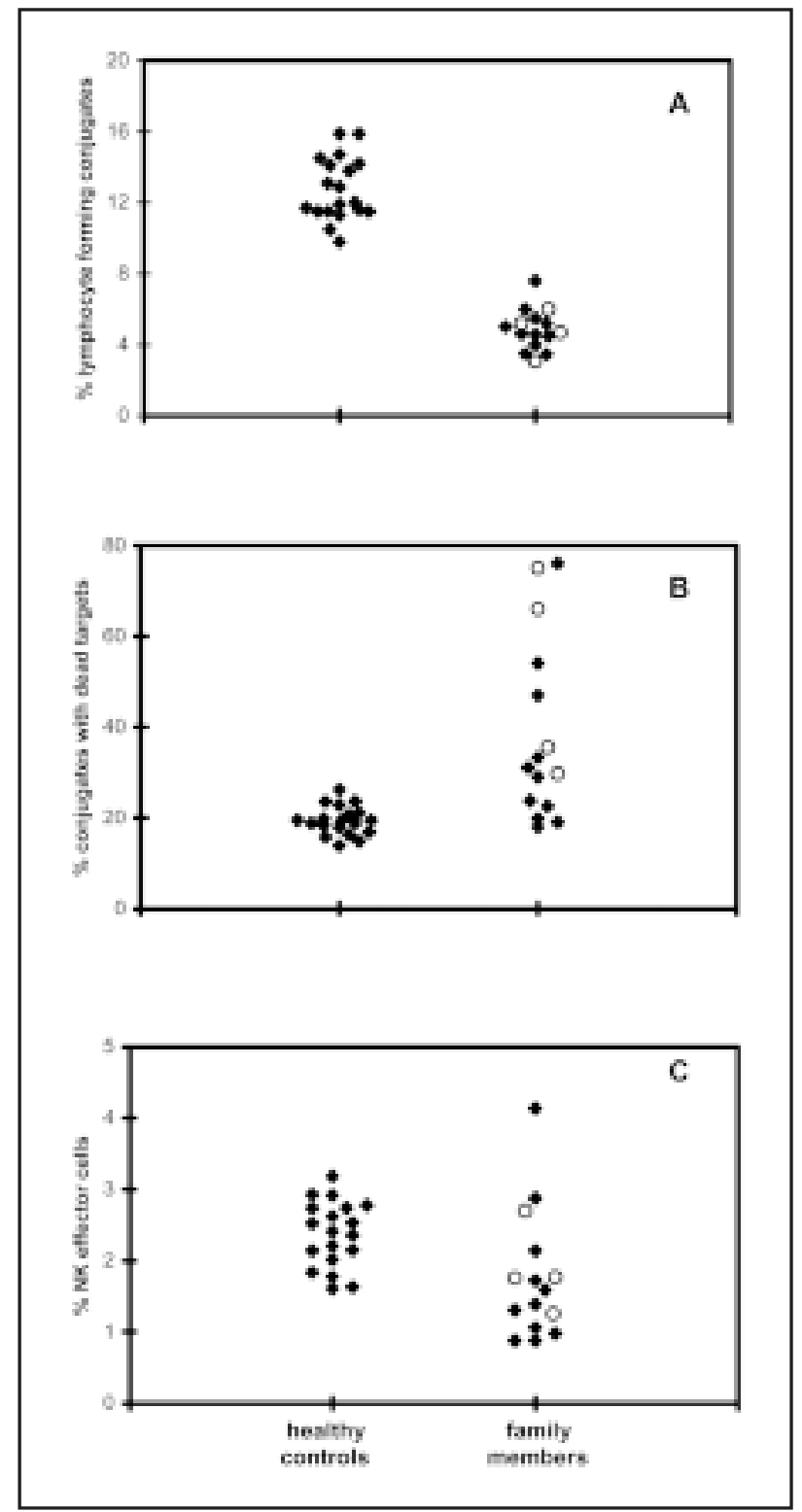

Fig 2. NK cell activity against $K 562$ target cells. Percentages of lymphocyte forming-conjugates (A), of conjugates with dead targets (B) and of NK effector cells (C) are shown for familial members ( $n=15)$ and for healthy controls $(n=19)$.

o cancer patients members; healthy family members.

\section{RESULTS}

The phenotypical distribution of peripheral blood lymphocyte subsets was altered in family members (Table 1). The percentage of total T cells $(C D 3+)$, helper/inducer $(C D 4+)$ circulating lymphocytes and CD4:CD8 ratio were significantly lower in family members when compared with the control group of the same age range.

The cytotoxic activity of NK cells against $\mathrm{K} 562$ target from family members and controls is presented in Table 2. The percentage of lymphocytes with ability to bind and forming conjugates with $\mathrm{K} 562$ cells, as well as the proportion of NK effector cells in the peripheral blood lymphocytes were significantly lower in family members when compared with the control group (Fig $2 \mathrm{~A}$ and $2 \mathrm{C}$ ). Figure $2 \mathrm{~A}$ shows that $100 \%$ of family members studied presented percentage of NK-K562 conjugates below the minimum value detected in the controls. However, lytic activity of NK cells, represented by the percent lymphocyte conjugates with dead target were significantly higher in family members than those observed in control group (Fig 2B). These results suggest that the impairment of NK cell activity in family members was mainly due to the extremely low percentage of conjugates formed between lymphocytes and K562 target cells.

Two cancer patients, members II-8 and II-10, were studied during illness - a female, 48 years old with glioblastoma (proband), and a man, 50 years old, with chronic mielocytic leukemia. One young man, 12 years-old, number III-22 was studied two years before the appearance of a benign bone mandible tumor (osteoblatoma) and again, two years after surgery and clinical recovery. His low levels of NK cytotoxicity and altered T cell subsets were detected before onset of mandible tumor and this alterations maintained at the same levels when examined again, two years after recovery. Another family member, a woman, 25 years-old, number III-19 developed malignant melanoma at the end of the study.

Only three healthy persons showed normal CD4:CD8 ratio in relation to control group. Two healthy people could be availed two times, during follow up of five years and showed maintenance of very low levels of lymphocyte forming conjugates.

\section{DISCUSSION}

In the present study, we observed altered T cells subsets and low NK cell function in cancer patients, but also in clinically normal, healthy unaffected persons. The corresponding values were comparable.

It could be surmised that the lower lymphocyte yield in the patients, and/or inhibitory factors in the sera, as discussed previously ${ }^{9}$ could be responsible for such a response. However, the same could not be true for unaffected people. While such study ${ }^{9}$ cannot suggest whether the depressed immunity level was secondary to onset of primary brain tumors, or precede it, now this family investigation does indicate that the low immune values can antedate the effect of disease progression and perhaps where involved in the etiological process. 
NK cell function has been studied in unaffected first-degree relatives of cancer patients in the past ${ }^{5,6,11}$ and our results are in agreement with those reports. However, these works studied breast or melanoma patients and their relatives ${ }^{4,5,11}$. Besides, these familial cancer studies have been employing the chromium release assay, to detect NK cell cytotoxicity against the target cell. This assay does not permit to know about conjugate formation and lysis functions of NK cells that is provided by the single-cell assay ${ }^{9,10} \mathrm{em}$ ployed in the present study. Strayer et al. ${ }^{5}$ described low cytotoxicity of peripheral blood mononuclear cells in normal individuals with high familial incidences of breast, colon rectal, lung and prostatic carcinoma. We do not have notice of similar studies in families with glioblastoma plus such a different kinds of malignacies as colon rectal carcinoma, pancreas carcinoma, melanoma, chronic myelocytic leukemia and bone tumor in a same family. These facts strengthen the role of cellular immunity, especially NK cell function, as a important modifying factor in determining the risk of cancer, including glioblastoma.

Our results permit to emphasize the importance of conjugate formation between NK cells and K562target cells that showed to be the most impaired function. Further investigations to clarify the characteristics of intercellular adhesion molecules may be important, as discussed elsewhere ${ }^{9}$.

Individuals with persistently low NK activity were described as prone to the development of malignancy ${ }^{10,12,13}$. The level of NK activity is considered as a stable individual trait, with fluctuates within a low, middle or high normal range characteristic for each individual, remaining the same unless disease intervenes ${ }^{13-17}$. Levy et al. ${ }^{15}$ described a low natural killer syndrome, where individuals who are usually healthy, but showed a pattern of persistently low NK citotoxicity were at risk for development of infectious diseases. They are called as individuals with low activity as those having NK function bellow either the studied group mean, or bellow the group lowest quartile, at two follow up assessments ${ }^{14}$.

Among the three family members with NK function studied twice, in a five years interval, the levels of activity were persistently low.

It is difficult, however, to ignore the previous considerations ${ }^{9}$ about impairment of cell-mediated and innate immunity induced by cytokines and neurokines shedded by tumors cells and immune system.
Recent study explain that low values of $T$ cells in patients with primary brain tumors is due to apoptotic elimination ${ }^{18}$.

Concluding these findings raise the possibility that reductions in inherited systemic natural cytotoxic activity may act in conjunction with inhibitory factors produced by primary brain tumors on immunity. Thus, the necessity of suitable biomarkers to identify individuals at risk from cancer families is recognized. NK cells function studies, as determined by singlecell assay may play an important role about this question. Also, NK adhesion alterations needs additional studies to investigate this phenomenon.

\section{REFERENCES}

1. Knudson AG. Hereditary cancer:two hits revisited. J Cancer Res Clin Oncol 1996;122:135-140.

2. Trinchieri G. Biology of natural killer cells. Adv Immunol 1989;47:187-376.

3. Whiteside TL, Herberman RB. The role of Natural Killer cells in immune surveillance against cancer. Curr Opin Immunol 1995;7:704-710.

4. Sheved LA, Joshi NN, Shinde SR., Nadkarni J J. Studies on functional status of circulating lymphocytes in unaffected members from cancer families. Hum Immunol 1998;59:373-381.

5. Strayer DR, Carter WA, Mayberry SD, Pequignot E, Brodsky I. Low natural cytotoxicity of peripheral blood mononuclear cells in individuals with high familial incidences of cancer. Cancer Res 1984;44:370-374.

6. Shevde LA, Rao NM, Joshi NN, Shinde SR, Ghosh SN, Nadkarni JJ. Natural killer cell function and genetic instability in unaffected individuals from breast cancer families. Eur J Canc Prev 1998;7:141-148.

7. Kashii Y, Giorda R, Herberman RB, Whiteside TL, Vujanovic NL. Constitutive expression and role of the TNF family ligands in apoptotic killing of tumor cells by human NK cells. J Immunol 1999;163:5358-5366.

8. Dubey DP, Alper CA, Mirja NM, Awdeh A, Yunis EJ. Polymorphic Hh genes in the HLA B $(C)$ region control natural killer cell frequency and activity. J Exp Med 1994;179:1193-1203.

9. Peraçoli MTS, Montelli TCB, Soares AMVC, et al. Immunological alterations in patients with primary tumors in central nervous system. Arq Neuropsiquiatr 1999;57:539-546.

10. Vargas-Cortes M, Hellstrom U, Perlmann P. Surface markers of human natural killer cells as analysed in a modified single-cell cytotoxic assay on poly-L-lysine coated coverslips. J Immunol Meth 1983;62:87-99.

11. Hersey P, Edwards A, Honeyman M, McCarthy WH. Low natural-killer cell activity in familial melanoma patients and their relatives. Br J Cancer 1979;40:113-122.

12. Stayer DR, Carter WA, Brodsky I. Familial occurence of breast cancer is associated with reduced natural killer cytotoxicity. Breast Cancer Res Treat 1986;7:187-192.

13. Levine PH, Whiteside TL, Friberg D, Bryant J, Colclough G, Herberman HB. Dysfunction of natural killer activity in a family with chronic fatigue syndrome. Clin Immunol Immunopathol 1998;88:96-104.

14. Levy SM, Herberman RB, Simons A, et al.. Persistently low natural killer cell activity in normal adults:immunological hormonal and mood correlates. Nat Immun Cell Growth Regul 1989;8:173-186.

15. Levy SM, Herberman RB, Lee J, et al. Persistently low natural killer activity, age and environmental stress as predictors of infectious morbility. Nat Immun Cell Growth Regul 1991;10:289-307.

16. Bovbjerg DH, Valdimarsdottir H. Familial cancer, emotional distress and low natural cytotoxic activity in healthy women. Ann Oncol 1993;4:745-752.

17. Whiteside TL, Herberman RB. Role of natural killer cells in health and disease. Clin Diagn Lab Immunol 1994;1:125-133.

18. Morford LA, Dix AR, Brooks WH, Roszman TL. Apoptotic elimination of peripheral $\mathrm{T}$ lymphocytes in patients with primary intracranial tumors. J Neurosurg 1999;91:935-946. 